\title{
CHARACTER EDUCATION FOR INDONESIA IN GLOBALIZATION ERA
}

\author{
DEWI SRI KUNING *)
}

\begin{abstract}
Tidak dapat dipungkiri bahwa keberadaan dan keberadaan globalisasi membawa dan memberikan banyak pengaruh dalam berbagai pada sektor pendidikan. Tentunya, ini akan menjadi suatu permasalahan jika sekolah/lembaga tidak mengamati secara komprehensip dan memperhatikan dengan baik terhadap setiap pengaruh dan perkembangan yang tampak dari globalisasi. Pendidikan menghasilkan kebiasaan hidup bagi seseorang. Ini bisa dilihat dari perubahan nilainilai budaya yang ada pada individu dan masyarakatnya. Pengimplementasian budaya berdasakan karakter pendidikan adalah hal-hal yang pokok dari pentingnya kebudayaan bagi seorang individu.
\end{abstract}

\section{Keyword: Character, Education, Globalization Era}

\section{Introduction}

Currently, the discourse of the urgency of the character education to bounce back and be a material concern as response to the various problems facing the nation, especially the problem of moral decadence such as corruption, violence, fights between students, inter-ethnic clashes and free sex behavior are likely to increase. According to Tilaar (2005: 17), that condition makes education today has been torn from its existence as an integrated part of the culture. Symptoms of separation of education from the culture can be seen from the symptoms as follows, namely: 1) culture has been restricted to matters relating to the arts, traditional dance, archeological including the affairs of temples and ancient buildings, tombs and traditional literature, 2) the values of culture in education has been limited to mere intellectual values, 3 ) the other case, the values of religion is not a matter of education but rather is a matter of religious institutions.

Ki Hajar Dewantoro in Tilaar (2005: 68), says that "culture cannot be separated from education, even culture is the base or basic education. This formulation reaches far into the future, because it is said to be not only educational based to an aspect of culture that is the intellectual aspect, but the culture as a whole. Culture became the base of such education must be national. Thus, the culture in question is the real custom namely a culture that lives in the community of Indonesian nationality. While, education has a way to 
realize the livelihood needs of all aspects of human life and the direction of the goal of education for elevating human level and dignity.

In relation to globalization, Arber (2009) asserts that globalization relates to the flow of markets, cultures, people, goods and services and ideas as they shift between local and global communities. Whereas, Stromquist and Monkman (2000) cite that globalization deals with economic, political, and cultural terms. Likewise, Gidden (2002) points out that globalization is political, technological and cultural, as well as economic. Nonetheless, Gidden emphasizes that it is a mistake if there is a group of people who solely see globalization from economic perspective. From these three viewpoints, we can conclude that globalization does not only relate to economy sector but it also deals with a variety of other such matters as political, culture, people, services, communication, information and technology, health, transportation, media, and fiscal including educational area.

\section{Definition and Development Strategy of Character Education}

From Cambridge Dictionary, meaning of culture is the way of life, especially the general customs and belief, of a particular group of people at a particular time. In the culture-based character education, culture is defined as something that is inherited or learned, then passes on what they learned and turn it into something new, that's the point of the educational process. If so, then the task of education as cultural mission must be able to process, namely: 1) the cultural inheritance; 2) help individuals in choosing the social roles and taught to perform those roles; 3 ) combining a variety of individual identity into a wider cultural scope; and 4) it must be a source of social innovation.

The stages above reflect the functional relationship between education and culture which contains two main things, namely: 1) reflective, education is a description of culture progressing, 2) progressive, education tries to renew, and the innovation of culture can reach the progress. Both of these things, line with the duties and functions of education are to continue or pass on the cultures and transform and develop the culture to achieve the progress of human life.

Character education is education that nurtures and promotes the ethnical, intellectual, social and emotional development of individuals. According to T. Lickona (2012), character education can be interpreted as an attempt to shape one's personality through education that the results are seen in a person's real action in the form of good behavior, 
honest, responsible, respecting the others' rights, hard work and so on. Character education represents a relationship between knowledge, values, and skills for success in life. Knowledge can be divided by two, they are general knowledge and specialized knowledge. Values are the beliefs and moral codes of a person or society about what is good and bad which tend to influence attitudes and behaviors. Skills are the abilities that individuals possess acquired via teaching, training, or direct experience that enable them to cope with the demands and challenges of everyday life.

Also Lickona (2012) gives several reasons about the important of character education:

- There is a clear and urgent need.

- Transmitting values and always has been the work of civilization.

- There is common, ethical ground, even in our value-conflicted society.

- Democracies have a special need for moral education.

- Character education is a doable job.

Character is like a bodybuilder continuously training to build muscle that he wishes that such practices become a habituation (Megawangi, 2007). Something potentially true character in human self, he then will be actual continuously developed, trained through the educational process. Reminding many values should be developed in character education, we can classify character education into three main components, namely: 1) religiously, 2) independence, 3) decency (Megawangi, 2007). In terms of teaching thecomponents above, Lickona explains there are three important components in building character education namely moral knowing (knowledge of morality), moral feeling (feelings of moral) and moral action (moral conduct).

Character is the particular combination of things about a person or place, things we can't see that make person or place different from others. There are 18 values in the educational development of the nation's culture and character designed by Kemdikbud Republic of Indonesia. Starting the school year 2011, the overall levels of education in Indonesia have to insert the character education in the educational process. The model of effective character education, according to the results of research conducted by (Zuchdi et al, 2009: 1-11) is using a comprehensive approach. The 18th character values are: religious, honest, tolerance, discipline, hard work, creative, independent, democratic, curiosity, the spirit of nationalism, patriotism, recognize excellence, friendly or communicative, love peace, love reading, caring environment, social care and responsibility (Ministry of National Education Curriculum Center, 2010: 10). The values of 
the character are described in the table as

follows:

TABEL 1

CHARACTER VALUES ACCORDING TO THE MINISTRY OF NATIONAL EDUCATION CURRICULUM CENTER

\begin{tabular}{|c|c|c|}
\hline No. & Character Values & Explanation \\
\hline 1 & Religious & $\begin{array}{l}\text { Attitudes and behavior that obey in doing the } \\
\text { teachings of their religion, tolerant toward the } \\
\text { implementation of the practice of other religions, and } \\
\text { live in harmony with other faiths. }\end{array}$ \\
\hline 2 & Honest & $\begin{array}{l}\text { Behavior based on an attempt to make himself as a } \\
\text { person who always trustworthy in word, action, and } \\
\text { jobs. }\end{array}$ \\
\hline 3 & Tolerance & $\begin{array}{l}\text { Attitudes and actions that respects differences of } \\
\text { religion, race, ethnicity, opinions, attitudes, and } \\
\text { actions of others who are different from themselves. }\end{array}$ \\
\hline 4 & Discipline & $\begin{array}{l}\text { Actions show orderly behavior and obey with various } \\
\text { rules and regulations. }\end{array}$ \\
\hline 5 & Hard work & $\begin{array}{l}\text { Behaviors indicate a really effort to overcome various } \\
\text { barriers in learning and assignments, as well as } \\
\text { completing the task as well as possible. }\end{array}$ \\
\hline 6 & Creative & $\begin{array}{l}\text { Think and do something to generate new ways or the } \\
\text { result of something that has been owned. }\end{array}$ \\
\hline 7 & Independence & $\begin{array}{l}\text { Attitudes and behavior that is not easy to depend on } \\
\text { others to complete tasks. }\end{array}$ \\
\hline 8. & Democratic & $\begin{array}{l}\text { Ways of thinking, being attitude and acting which } \\
\text { assesses the same rights and obligations of himself } \\
\text { and others. }\end{array}$ \\
\hline 9. & Curiosity & $\begin{array}{l}\text { Attitudes and actions which seek to know deeper and } \\
\text { spread of something learned, seen, and heard. }\end{array}$ \\
\hline 10. & National spirit & $\begin{array}{l}\text { Ways of thinking, act, and having knowledge hat puts } \\
\text { the importance of the nation and country above self- } \\
\text { importance and group. }\end{array}$ \\
\hline 11. & Love homeland & $\begin{array}{l}\text { Ways of thinking, being attitude, and acting that show } \\
\text { loyalty, caring, and high appreciation toward } \\
\text { language, physical environment, social, cultural, } \\
\text { economic, and political nation. }\end{array}$ \\
\hline
\end{tabular}




\begin{tabular}{|c|c|c|}
\hline 12. & $\begin{array}{l}\text { Appreciating the } \\
\text { achievements }\end{array}$ & $\begin{array}{l}\text { Attitudes and actions that encourage him to produce } \\
\text { something useful for society, and recognize and } \\
\text { respect other people's success. }\end{array}$ \\
\hline 13. & $\begin{array}{l}\text { Friendly and } \\
\text { communicative }\end{array}$ & $\begin{array}{l}\text { Actions show a sense of fun to talk, hang out, and } \\
\text { work together with others. }\end{array}$ \\
\hline 14. & Love peace & $\begin{array}{l}\text { Attitudes, words, and actions that cause others to feel } \\
\text { happy and safe on the presence of himself. }\end{array}$ \\
\hline 15. & Love reading & $\begin{array}{l}\text { Habits provide time to read a variety of literature that } \\
\text { gives virtue for him. }\end{array}$ \\
\hline 16. & $\begin{array}{l}\text { Caring } \\
\text { environment }\end{array}$ & $\begin{array}{l}\text { Attitudes and actions which seek to prevent damage } \\
\text { to the surrounding natural environment, and develop } \\
\text { efforts to repair the environmental damage that has } \\
\text { occurred. }\end{array}$ \\
\hline 17. & Social care & $\begin{array}{l}\text { Attitudes and actions have always wanted to help } \\
\text { other people and communities in need. }\end{array}$ \\
\hline 18. & Responsible & $\begin{array}{l}\text { Attitudes and behavior of people to do his duties, he } \\
\text { should do, to himself, community, environment } \\
\text { (natural, social and cultural), the country and god } \\
\text { almighty one. }\end{array}$ \\
\hline
\end{tabular}

The principles used in the development of character education (Curriculum Center Kemdikbud) as follows: 1) sustainable; implies that the values of character development is a process that is not stopping, started from the beginning of learners entered until completion of an educational unit, even after graduation and plunge into society. 2) through all subjects, self-development, and school culture, as well as local content; requires that the process of developing character values carried by each subject, as well as in curricular and extracurricular activities, 3) the value is not taught, but developed and implemented; consist the meaning that the material value of the character is not used as a subject as when teaching a concept, theory, procedure, or facts in religious subjects, Indonesian, civics, science, social studies, mathematics, physical education and health, arts, and skills, or other subjects. Teachers do not need to change the subject to develop character values of the nation. Moreover, teachers do not have to develop the learning process, specifically to develop value. One thing you always have to remember that a learning activity can be used to develop skills in the cognitive, affective, and psychomotor, 4) the educational process is 
done by the learners actively and fun. This principle states that the value of character education is done by the learners, not the teachers.

Furthermore, what mission or goal should be targeted in character education? 1) Cognitive, fills the brain, taught from not knowing to knowing, and the next steps can cultivate the mind, so that he can use the minds intelligence to be a smart intelligence. 2) Affective, related to the feelings, the emotional, the formation of attitudes within one's self with the formation of attitudes, sympathy, antipathy, love, hate, and so on. All these attitudes can be classified as emotional intelligence. 3) Psychomotor, related to the actions, behavior, and so on.

According to Hersh (1997), among the various developing theories, there are six theories are widely used, namely: the rational development approach, the consideration approach, the values clarification approach, the cognitive moral development approach, and social behavioral approaches. In contrast to the classification, Elias (1989) classifies the various theories which grows into three, namely: the cognitive approach, the approach affective, and behavioral approach. This classification according to Rest (1992), is based on three elements of morality, which is used to be the foundation of the study of psychology, namely: behavioral, cognitive, and affective.

There are five approaches like below:

\section{Incultation Approach}

Inculcation approach is an approach that gives an emphasis on the cultivation of social values in students. According Superka et al. (2000), the purposes of education based on the value of this approach are: First, received a certain social values by students; second, changing the values of students who do not conform to social values as desired. The method used in the learning process according to this approach include: exemplary, positive and negative reinforcement, simulations, role play, and others.

\section{Cognitive Development Approach}

This approach is said as approach cognitive development because its characteristic emphasis on cognitive aspects and development. This approach encourages students to think actively about moral issues and in making moral decisions. Moral development based on this approach is seen as a development level of thinking in making moral judgments, of a lower level to a higher level (Elias, 1989).

\section{Values Analysis Approach}

Value analysis approach gives an emphasis on the development of students' ability to think logically, by analyzing the 
problems related to social values. If compared with the cognitive development approach, one of important differences between the two is that the value analysis approach more emphasis on the discussion of the problems that includes social values. Meanwhile, the cognitivedevelopment approach emphasis on the individual moral dilemmas. (Superka, 2000).

\section{Values Clarification Approach}

Values clarification approach gives an emphasis on efforts to help students in assessing their own feelings and actions, to increase their awareness of their own values. Values educational purposes based on the approach, there are three. First, it helps the students to recognize and identify their own values and the values of others; Second, it helps students, so that they are able to communicate openly and honestly with others, dealing with its own values; Third, it helps students, so that they are able to use their ability to think rationally together and emotional awareness, to understand the feelings, values, and behavior patterns of their own.(Superka, 2000).

\section{Action Learning Approach}

Action learning approach gives an emphasis on the business providing the opportunity for students to perform moral deeds, either individually or together in a group. Superka, et. al. (2000) concluded that there are two main goals of moral education based on the approach. First, provide an opportunity for students to perform moral actions, either individually or together, based on their own values; Second, encourage students to see themselves as individual beings and social beings in association with others, who do not have complete freedom, but as citizens of a society, which must take part in a democratic process. The methods of teaching used in the value analysis approach and values clarification are also used in this approach. The other methods are certain projects to be done in school or in the community, and practice skills in the organization or related among others.(Superka, 2000).

The Ministry of Education and Culture of the Republic of Indonesia has made a policy to integrate character education into the curriculum, ranging from pre-school level, primary education, secondary education, both of formal education and non-formal to university. Character education express that character education becomes a necessity because education does not only make learners intelligent mind, but also have good character and manners so that its presence as a member society becomes meaningful, both for themselves and others. This is done because at this time many learners are more concerned with learning outcomes without concerning the 
character and disposition. The splendor of the learners to cheat in order to obtain good grades, do not have manners, brawl, ditching school, and racing on the highway becomes a basic necessity to apply character education in teaching in schools, including the teaching of Islamic Education (PAI).

So, what's wrong with the character educationor our character? Buchori argues that the character education is formulated into religious studies, citizenship lessons, and manner lesson during the main program is the introduction of values cognitively itself. In fact, character education should bring the learners to the introduction of the values cognitively, value appreciation affectively, and finally into practice in the real value (MONE, 2010: 6). If we want to see a better life for next generations, said Zubaedi (2013: 24), education should be directed to build awareness of the importance of values and meaning behind anything we do. In relation to establish the value and character of the education system, Agustian says two things, namely required an education design not only prioritizes intelligence quotient (IQ), but also emotional intelligence (EQ) and spiritual intelligence (SQ).

\section{CONCLUSION}

Education cannot be separated from culture. Education is a product of human culture and become part of the culture. Education intends to pass down, forward, describe patterns and currents emerging culture. Education also seeks to transform the cultural values in order to achieve both individual and community progress. Position and function of education as a center of cultural development, study centers, and the development of sciences for the progress of human civilization. The Implementation of culture-based Character Education outlines the importance of exemplary elements. Besides that, it should be accompanied by efforts to create a social environment that is conducive for the students, either in the family, at school and in the community. Thus, the implementation of Character Education will be more memorable in order to establish the personality of students. The arrangement of character education should give a balanced emphasis to aspects of the value and process of teaching. Besides that, it should also give a balanced emphasis to the development aspect of the intellectual, emotional and spiritual students. 


\section{References}

Arber, Ruth. (2009). Internationalising the curriculum. Melbourne. Deakin University.

Giddens, Anthony. (2002). Runaway world: how globalization is reshaping our lives. Profile Book, London. 6-19.

Hersh, R.H., Miller, J.P. \& Fielding, G.D. (1997). Model of Moral Education: an Appraisal. New York: Longman Inc.

Lickona, T. (2012). Character Development in The Family. Dlm. Ryan, K. \& Mclean, G.F. Character Development in Schools and Beyond. New York: Praeger.

Megawangi, Ratna. (2007). Character Parenting Space, Publishing House. Bandung: Mizan.
Stromquist, Nelly P; \& Monkman, Karen. (2000). Globalization and Education: Intergration and Contestation across Cultures. United States of America: Rowman \& Littlefield Publishers, Inc.

Superka, D.P. (2000). A Typology of Valuing

Theories and Values Education Approaches. Doctor of Education Dissertation. University of California: Berkeley.

Tilaar, H.A.R. (2005). Pendidikan, Kebudayaan, dan Masyarakat Madani Indonesia, Strategi Reformasi Pendidikan Nasional. Bandung: Remaja Rosdakarya.

Zubaedi. (2013). Desain Pendidikan Karakter Konsepsi dan Aplikasi dalam Lembaga Pendidikan. Jakarta: Kencana Prenada Media Group. 